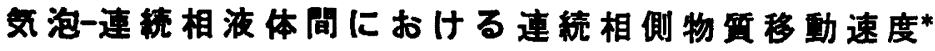

\author{
城塚 正**平田彰** \\ 早稲田大学理工学部 応用化学科 化学工学分科
}

藉官：著者らは先に平面状の異相接触界面を通して の物質移動速度におよぼす表面浪度の時間的変化と界面 速度の影疃について，境界層理詥を咅用して理論的解 析を行ない，特に界面速度の重要性を定田的に評洒し だ1。次にこの解析結果を液滴一連䊀相液体間における連 綪相側物質移動に払張展開し，界面速度を考虑すること により, 現存するほとんど全ての定量的データを，固体

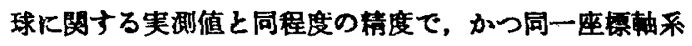
により珫一的に相関できることを明らかにしだ1。

本報では，これらの理詥展閏をさらに気泡一連結相液 体間の連続相侧物質移動に拉張南用を行なった。その結 果, 本理諭は佣体模型および夜滴のみならず，気泡系に

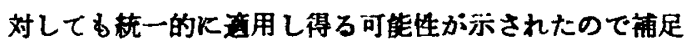
報告する。

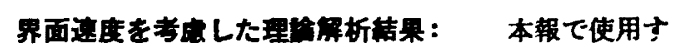

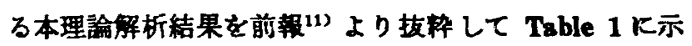
した。なおこれらの詳紐は前報に速べてあるので割受す ろ。

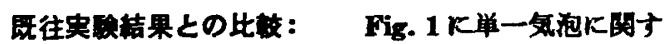
る Redfield-Houghton") の実検結果との比傚の一例を示 した。彼らは気泡径が 5 16 mm の $\mathrm{CO}_{2}$ 泡より，和々

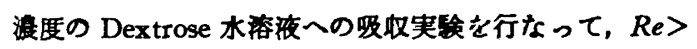
10 では $S h /(\operatorname{ReSc})^{1 / 2}$ の值が $R e$ 数の增加と共に影著に 増加し，従来から提出されているいずれの理論によって も説明できない.と述へててい。しかし Fig. 1 によれば, 果面速度を考虑した本理諭解析により，この㑯向を説明 できることが判る。すなわち， $R e$ 数の增加により，気 泡界面の界面速度が增加し，このため物質移䖝速度が增 加するるのと解釈することがでさる。

気泡径が非常に大きくなると気泡上旱速度る大きくな $\eta$ ，究極的には $u_{\infty} / u_{\infty} \approx 1$ となり，本理論に上る解析結

- CContinuous Phase Mass Transfer from Bubbles in GasLiquid System>

Received on March 6, 1970

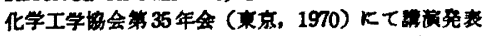

* Tadashi Shirotsuka and Akira Hirata (Chem. Eng. Course, Dept. of Appl. Chem., School of Eng. and Sci., Waseda Univ, Tokyo, Japan)
果はボテンシャル流れにおける Calderbank-Lochiel" の理論解に近似する。いま，Fig. 2*

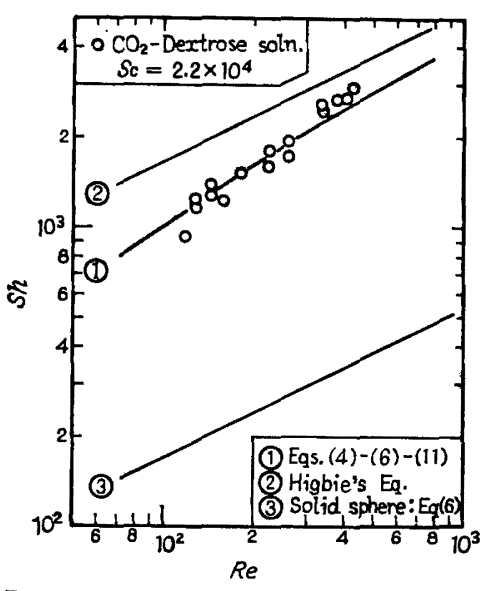

Fig. 1 Some comparisons with Redfield and Houghton's data') for single bubbles

Table 1 Summary of theoretical results

(1) Continuous phase mass transfer rate

$\frac{S h}{S h_{0}}=\sqrt{1+1.9 \frac{\mu_{\infty}}{u_{\infty}}} S c \frac{1}{\sigma}\left(\frac{\omega_{\infty}}{\omega_{\infty}}\right), 0<\frac{\mu_{x_{0}}}{\mu_{\infty}}<1$

where, sphere: $\left(S h_{0}\right)_{0}=2+0.6 R e^{1 / 2 S c^{1 / 3}}$

oblate spheroid: $\left(\frac{S h_{0 b}}{S h_{t}}\right)_{0}=\left(\frac{A_{0}}{A_{0 b}}\right)^{1 / 2} E^{1 / 4}$

where, $\left(\frac{A_{0}}{A_{\infty}}\right)=\frac{2 E^{1 / 3}\left(E^{2}-1\right)^{1 / 2}}{E\left(E^{2}-1\right)^{1 / 2}+\ln \left(E+\sqrt{E^{2}-1}\right)}$

opherical cap: $\left(\frac{S h_{s e}}{S h_{e}}\right)_{0}=1.58 \frac{\left(3 E^{2}+4\right)^{2 n}}{E^{2}+4}$

(2) Interfacial velocity

$\frac{u_{0}}{u_{\infty}}=a_{1}+\frac{a_{2} R e}{a_{3}+R e}-\frac{a_{1}}{\sqrt{a_{5}+R e}}$

where, $a_{1}=\frac{2}{3(1+x)}$

$a_{2}=1-a_{1}$

$a_{s}=\frac{64(1+k)^{2}(1+3 k)(2+3 k)^{2}}{4(1+k)(2+3 k)^{2}-\left[1+(7 k)^{1 / 2}\right]^{2} \pi}$

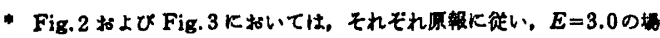
合についてい並嗼した。 


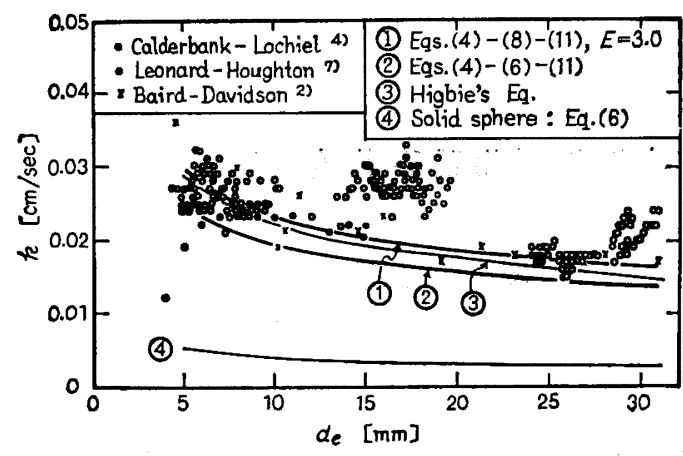

Fig. 2 Continuous phase mass transfer coefficient for single large bubbles $\left(\mathrm{CO}_{2}\right.$-water: $\left.\mathrm{Sc}=570\right)$

ける単一大気海に関する諸実駼結果との比较を示した。 Fig. 2 に上れば，本理論に上る解析結果はこれらの実験 結果と大され一致している。また，同時にボテンシャル 流れの理論である Boussinesq 式》，す怰ち， $t=d_{e} / u_{\infty}$ とおいた Higbie 式をる示した。従来，ガス吸収笑験に おいては，一般的に Higbie 式が適用できるとされてい るか，本理論による解析結果はこの通説にもよく合致し ている。

次に，Fig. $3^{*}$ には気泡擋拌楮に関する一例として， Calderbank and Moo-Yung ${ }^{5)}$ とる $\mathrm{CO}_{2}$ ークリセリン

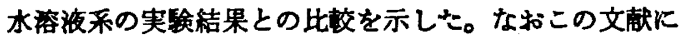
は上吕速度が明示されていないので, Allenの式", す なわち， $u_{t}=(1 / 4)\left(\Delta \rho^{2} g^{2} / \rho_{c} \mu_{c}\right)^{1 / 3} d_{0}$ により上昇速度を 推算して本理詥値を示した。彼らは気泡径により 筑用が存在することを認めている。すなわち，小気泡 (0.6 mm 以下) と大気泡 (2.5 mm 以上) ではそれぞれ 物質移動保数の值が一定であるが，0.6 2.5mm の中間 項城では物質移動係数が気泡径注䚾比例して增加する としている。彼らは小気泡と大気泡の両極端の場合につ いては理論的に説明できるが，中間領城については従来 の理論ではいずれる锐明できないと述へている。その 後， Gal-Or-Walatka' は高 $\mathrm{Pe}$ 数のストークス流にお ける Levich の解のより Fig. 3 の点線のことさ中間領域 を满足する解を得ている。しかるにこの理論では逆に小 気泡および大気泡における現象が説明できなくなる。 Fig. 3 Kよれば，本理論解析は，特に気泡形状がキノン 笠状になっていることを考虑すれば，これらの3つの頌 域を全て满足することが判る。なお Fig. 3 の䅋囲より 大なる気泡径では $u_{\infty} / u_{\infty} \approx 1$ となり，この場合は Fig. 2 に示されるよらに物質移動係数は気泡径が增大するにつ れて逆に減少するようになる。したがって一般的に，あ

\footnotetext{
- 斯ベーシ脚注合圆
}

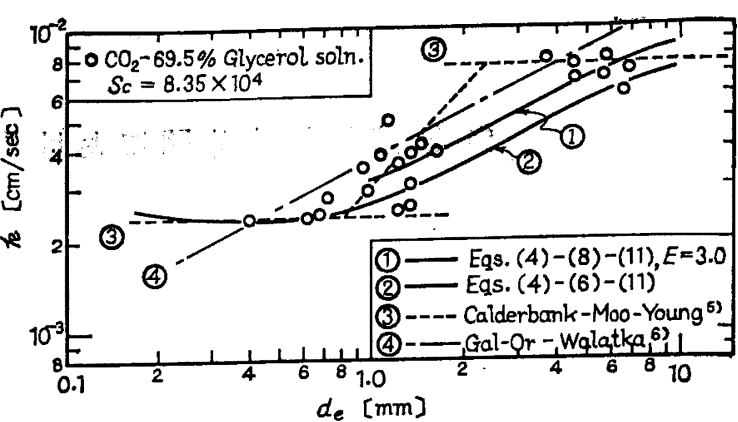

Fig. 3 Some comparisons with Calderbank and Moo-Younges data5) for transition from small bubbles to large bubbles in aerated mixing vessels

る気泡径において物質移動係数の極大值が存在すること が判る。これらのことから, 従来気一夜系の場合におい、 ては，一般的にポテンシャル流れの取り报いが多かった か，液液系の場合と同様化，接触界面近傍における流体 力学的条件をむ考虑する必要があると考えられる。

结著者らの前報における理論解析の結果を気泡か らの物質移動に抾張薏用した。3種の代表的な既往デー タと比較した結果, 従来説明し得なかった物質移動現象 をも説明することができた。このことより，㓮体模型・ 液滴および気泡からの物質移動は界面速度を考虚するこ とにより梳一的に取り报える可能性を示した。したがっ てまた前報で得た結論，すなわら，異相接触界面におけ 万物質移動機粠の研究に界面速度の考虑が必須であるこ とが，気泡系に対してるいえることが確認できた。

Nomenclature: Same as that in previous paper ${ }^{112}$

\section{Literature rited}

1) Allen, H.S.: Phil. Mag., 50, 323 (1900)

2) Baird, M.H.I. and J.F. Davidson: Chem. Eng. Sci, 17, 87 (1962)

3) Boussinesq, J.: J. Math. Pure Appl, 6, 285 (1905)

4) Calderbank, P.H. and A.C. Lochiel: Chem. Eng. Sci., 19, 485 (1964)

5) Calderbank, P.H. and M. B. Moo-Young : ibid., 18, 39 (1961)

6) Gal-Or, B. and V.V. Walatka : AVChE Journal, 13, 650 (1967)

7) Leonard, J.H. and G. Houghton: Chem. Ene. Sci., 18, 133 (1963)

8) Levich, V.G.: "Physicochemical Hydrodynamics", Prentice-Hall, Englewood Cliffs, N.J. (1962)

9) Redfield, J. A. and G. Houghton: Chem. Eng. Sci., 20, 131 (1965)

10) Shirotsuka, T., A. Hirata and K. Sakai : Kagaku Kögaku 33. 168 (1969)

11) Shiroteuka, T. and A. Hirata: ibid, 35, 78 (1971) 
液中を上昇する単一気泡の運動（柘植秀樹・日比野真一，化 学工学, $35,65 \sim 71$ (1971))

灰中を上界する棈円体状空気泡の上年速度, 上升経路の変動周期，

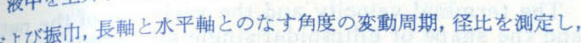
上年経路变動の周期と，振巾は，気泡の発生方法や污染系，精製系 てかかかわらず，無次元群で整理できることを見いだした。さらに経 路変動の周期と角度変動の周期はほぼ一一致し，径比変動周期がそれ らの約 $1 / 2$ に相当することと，それらの位相差を考虑し，液中を上 时する気泡の简监な 2 次元モデルる提出した。

浮遊粒子層内における粒子の相対運動について（宮内照勝・ 山田健夫, 化学工学, $35,71 \sim 77$ (1971))

厸散や反応操作に和ける粒子・流体接触の基礎として浮遊粒子層 内を渾動するトレーサ粒子（層粒子とは異なった粒径をもつ）の举 動を実験的に研究した。実験結果によれば層内でのトレーサ粒子の スリッフ速度を与党る関数 $\phi$ (Eq. (10) て定義される量) は粒子 レイノルズ数が 20 〜 500 の簌囲で層の空間率のみの関数となり, それ以下では粒子レイルルズ数と空関率との関数となった（Fig. $5 ， 6)$ 。また関数 $\phi$ は混合粒子の沈降速度をよく表現できることが 判明した。

液滴一連続相液体間における連続相側物質移動速度（城塚正 ·平田彰, 化学工学, 35, 78 84 (1971))

界面流動を伴了平界面接触における著者らの既発表の理論解析を 液滴から連続相側への物質移動速度に払張展開した。さらに液滴の 界面速度の推算のために広範用な物性值および $R_{e}$ 数に対する近似 表示式を得た。艮往の実験結果を界面速度を含む項で再整理し，本 理鏸解析の結果と比較したところぎわめてよく一致し，固体球に関 する実测值と同程度の精度で，かつ同一座標軸系で統一的认相関与 ることができた。界面速度は今後の物質移動機構の研究においてき

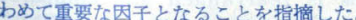

自由上昇下にある液滴を通しての物質移動機構一分散相側物 質移動速度について一(原田 誠・江口 弥, 化学工学, 35, 85 91 (1971))

トルェン滴一水系, $n$ ・ブタノール滴一水系におお方分散相側物筫 移動機棈と液滴の举動との関係を実験的に検討した。液滴佳の小さ 儿範围では，液滴内部に存在する循環流や乱れによる滴内混合状熊 によって物質移動速度は律せられる。振動現象を伴って上年する液 商については，滴内混合が激しい場合，分散・連続両相の物質移動 保数とも同一の相関式て表わされ，物質移動抵抗は振動現象に上り 律せられる。以上の結果を基にして，滴内混合の緩慢な状熊から しい状態に至る広範囲の物質移動速度を滴内混合の補正パラメータ を用いて定量化しだ。また，掁動液滴については，一般比浸透理論 を用いた Angelo の式と界面更新説に立脚した物質移動保数の式 とを比較し，見挂上 Angelo の式が実測值をよく表現することを 確哂した。

湿式分級について一循環流型多段湿式分級装置の研究開発一 (吉野善弥・三次隆・村松豊司 • 可知崇好・吉田靖 ・ 岡島裕明 - 野島正一・神吉純一, 化学工学, 35, 91 98 (1971)

1）湿式分級に関する基礎的考察を行ない，分級過程に和ける粓 子分別機構とくにその部分分級效率や粒子回収量などに関する一般 的関保式を導いた。2）回分湿式分級試験などを行なって，粒子

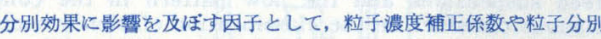
伱数などに関する実験式を求めた。 3）連続湿式分粐に関する甚 的考察を行ない，連続湿式分級過程における粒子分别効果に対寸 る槽内流動の影響ならぴに沈積粒子群に同伴される粒子量の影㗽な どに関する一般的関係式を導いた。 4) 上記一連の結果などにる とづき連続湿式分級試験を行ない，とくに分級槽本体外周壁に中間 沈降槽を設置した循環流型多段湿式分粐試験装置を試作して連続実 験を行なった結果, 比較的に分級精度の高い生成物が，中間沈降槽の 段置数ならびに操作条件に応して得られることが明らかになった。

\section{多孔板ガス吸収塔の流量変動による動特性一非定常流動特性} の影響一（城塚 正・荒川秀夫，化学工学， 35，98 104 (1971))

気液接触多孔板塔の液よよびがス流量変動に上る動特性解析の実 験を空気 $\left(\mathrm{CO}_{2}\right)$ 一水 $(\mathrm{NaOH})$ でおこなった。液㳻度応答の㨽定結 果上非定常流動モデルを絽込んだ動特性モデルとを比較検討した。 塔の構造因子 (開孔比等) のちがいによって，ガス流量変動による 応答が逆転する場合があることがかかった。その原因は段上液の登 流管への逆流現象の有無大小によると思われる。さた一段当りの吸 収速度が大きな塔汪ど流量変動の影蠁が大きくなる。流動の時定数 と物質移動の時定数とを比較した結果，前者は無視できないと思わ れる。

\section{<化学工学データ>}

メタノール・エタノール・水・塩化カルシウム系の気液平街

データ（大江修造・横山公彦・中村正一, 化学工学, 35 , 104 107 (1971))

メタノール・ェタノール・本系に塩化カルンウムを $16.7 \mathrm{wt} \%$ 和（室温）に溶解させた場合の気液平衡を大気圧下で測定し，匃 液平衡曲線を得た。塩化カルシウムの添加によりメタノールのエタ くールに対する相対揮発度は堿少するがエタノールの水に対する相 対掩発度は增大している。
䝫酸 + 水 + ベンゼン系および酢酸+水+トルエン系の液液平 衡（井口昭洋・布施憲司，化学工学，35，107 110 (1971))

酶酸+水十ベンセン系および酶酸十水十トルエン系の $25^{\circ} \mathrm{C}$ の淮 液平衡を湘定し、鍙解度曲線とタイーラインのデータを得た。ブレ イトポイントを

$$
\log x_{w}:\left(y_{w}-x_{w}\right) / x_{w}
$$

の相関関倸を利用して求めた。ここで， $x_{w}$ は炭化水素相内の酶酸 重量分率で， $y_{w}$ は水相内の酢酸重量分率である。

酶酸+水+崖化水素系のプレイトポイントにおける酸の濃度と各 炭化水菜の水への溶解度との間にはつぎのように定性的な関係が見 られる。

$\begin{array}{lcc} & \text { 溶解度 } & \text { 酸濃度 } \\ n \text { ーヘキキン } & 0.11 & 0.470 \\ \text { シクロヘキサン } & 0.08 & 0.510 \\ \text { ヘンンン } & 0.06 & 0.526 \\ \text { トルェン } & 0.05 & 0.567\end{array}$

石油系炭化水素の気液平衡関係について（道下次男・荒井康 彦・斎藤正三郎, 化学工学, 35, 111 116 (1971)

石油系炭化隶素の気液平衡関係を 9 つの二成分采，および，20 の三成分系について，大気压下で湘定した。これらの実㑚値により Wilson 式の定数を決定しこれらの定数が三成分系の気液平衡の 推算に有效であることを確めた。さらら BWR 式によるこれらの 系の気液平衡の推算を計子た。

\section{〈技術報告〉}

溢流部のない(棚 (漏れ棚) 上におけるガス (蒸気) の上限速 度 (内山久·平尾一成·米野直彦, 化学工学, $35,116 \sim 122$ (1971)

著者らの実験データとソ連文献值を用いて堰と溢流部のない棚段 塔中に甜ける安定作業域のガス (蒸気) の上限速度を求める計算式 を得た。棚は (a) 開孔比 $F_{c} \geqslant 0.16$ の多孔板棚，(b) 格子棚と $F_{c}<0.16$ の多孔板棚の 2 群飞分類し, 各群に対して $\rho_{g} / \rho_{l}$ の範囲

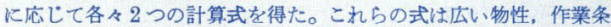
件，幾何学的因子の範囲にわたって適用され，既往の式よりも精度 が高い。

\section{<寄 書 $>$}

気泡一連続相液体間における連続相側物質移動速度（城塚正 • 平田彰, 化学工学, 35，123 124 (1971))

著者らの前報の理論解析を気泡からの連続相側物質移動に执張邇用 した。単一気泡に関する Redfield-Houghton 拈よび Calderbank-Lochiel，さらに文泡筧拌槽に関する Calderbank-MooYoung の実験結果と比較した結果，これらのデータをよく説明す ることができた。今後異相接触界面に特ける物質移動機構を研究す るには界面速度を考虑した上でなさねばならないことが指摘される。 
Liquid-Liquid Equilibria of the Systems Acetic Acid + Water + Benzene and Acetic Acid + Water + Toluene, A. Iguchi (Musashi Inst. of Tech.) and K. Fuse (Tokyo Inst. of Tech.)

Kagaku Kögaku, 35, 107 110 (1971)

Solubility curve and tie-lines were determined for the systems acetic acid+water+benzene and acetic acid+water+toluene at $25^{\circ} \mathrm{C}$.

The concentration of acetic acid at plait point was obtained from extrapolation of the following correlation line,

$\log x_{w}$ vs. $\left(y_{w}-x_{w}\right) / x_{w}$
where $x_{w}$ is acid concentration (wt. fraction) in hydrocarbon layer and $y_{w}$ is acid concentration (wt. fraction) in water layer.

For the acetic acid+water+hydrocarbon systems, it seems there is a qualitative relation between conhydrocarbon in pure water as follows:

$\begin{array}{lcc} & \text { solubility* } & \text { wt. fraction } \\ \text { chexane } & 0.11 & 0.470 \\ \text { cyclohexane } & 0.08 & 0.510 \\ \text { benzene } & 0.06 & 0.526 \\ \text { toluene } & 0.05 & 0.567\end{array}$

Vapor-Liquid Equilibria of Hydrocarbons at Atmospheric Pressure, T. Michishita, Y. Arai and S. Saito (Tohoku Univ.)

Kagaku Kögaku, 35, 111 116 (1971)

Vapar-liquid equilibrium data of nine binaries and
Vaporitak two ternaries of hydrocarbons were obtained at atmospheric pressure. By using these data, the binary-interaction parameters of Wilson equation to be capable of predicting vapor-liquid equilibria of ternary systems.

The prediction of vapor-liquid equilibria by BWR equation were also attempted for these systems.

<Technical Report>

Maximum Permissible Gas (Vapor) Velocity in Plate Tower without Downcomer, H. Uchiyama, K. Hirao and N. Meno (Shizuoka Univ.

Kagaku Kōgaku, 35, 116 122 (1971)

Using our experimental data and Soviet literature data, we obtained the experimental equations for the maximum allowable gas (vapor
plate tower without downcomer.

Classifying the plates in two groups: (a) perforated plates $\left(F_{c} \geqslant 0.16\right)$, (b) grid plates and perforated plates $\left(F_{c}<0.16\right)$, we derived the calculating formula for each group.

For (a) group, two equations are obtained for the ranges of $\rho_{g} / \rho_{l} \times 10^{3} \leqslant 0.838$ and $\geqslant 0.838$ (error $\pm 13 \%$ ), for the range of $\rho_{q} / \rho_{l} \times 10^{3} \geqslant 1.20$ and $\leqslant 1.20$ (erro $\pm 15 \%)$.

\section{$<$ Short Communication $>$}

Contiouous Mass Transfer from Bubbles in Gas Liquid System, T. Shirotsuka and A. Hirata (Waseda Univ

Kagaku Kögaku, 35, 123 124 (1971)

This study deals with the continuous phase mass transfer from bubbles and a further application of the mass transfer theory counted with flowing inter face which the authors previously reported.

The theoretical results agrees favorably with the experimental results by Redfield-Houghton and by transfer rate from single bubbles, and with the data by Calderbank-Moo-Young on the continuous phase mass transfer from bubbles in aerated mixing vessels. The above comparisons suggests that the future study of interphase mass transfer should pay particular attention to the interfacial velocity.
Mechanism of Mass-transfer through a Drop of Free Rise on the Mass-Transfer Rate inside a Drop-, M. Harada and W. Eguchi (Kyoto Univ.) Kagaku Kögaku, 35, 85 91 (1971)

The relation between drop behavior and masstransfer inside a drop was experimentally clarified, using the systems of toluene drop-water and $n$-butanol drop-water. In the range of drops with small diameter, mass-transfer rate is controlled by the degree of mixing inside a drop caused by circulation flow and turbulence. For the drop accompanied with oscillation, mass-transfer coefficients both for con tinuous and dispersed phases are correlated by a same equation and $\mathrm{m}$
trolled by oscillation.

trolled by oscillation.
Based on the above experimental results, a model was proposed, which express mass-transfer rate through a drop in states from mild to violent mixing inside the drop. For oscillating drops, the empirical equation for mass-transfer coefficient was compared with Angelos' generalized penetration model and the equation derived on surface renewal model. It was clarified that Angelos' equatio

observed results, apparently.

Studies on Wet-Classification, Z. Yoshino, T. Mitsugi, T. Muramatsu, T. Kaji, Y. Yoshida, H. Okajima, S. Nojima and J. Kanki (Tokyo Univ. of Agricul. \& Tech

Kagaku Kögaku, 35, 91 98 (1971

The mechanism of size separation in the wet classi fier was studied fundamentally, and the effects of solid content and or particle size distribution in the feed suspensions and the flow pattern in the con 作 as partial classification efficiency and/or solid re moval percent.

Based on the above considerations and experimental results, we have developed the high efficiency classi

Dynamics of Perforated Plate Gas Absorption Column with Gas and Liquid Flow Change-Effect of Unsteady State Liquid Hold-Up CharacteristicsT. Shirotsuka and H. Arakawa (Waseda Univ.)

Kagaku Kōgaku, 35, 98 104 (1971)

The experimental transient responses obtained on The experimental transient responses obtained on
a 3-in.i.d. five plate absorption column operating with
the system air-carbondioxide-water-sodium carbonate. The theoretical model which contain unsteady state hydraulics is given for unsteady state behaviour of a plate gas absorption column and theoretical transient
responses are derived. The experimental responses are good agreement with theoretical responses.

The first, the patterns of the responses are influenced by the structure factors such as a free area and this phenomena shows a residence of the backward flow for step increase in gas flow rate. The second, the greater absorption rate, gas and liquid flow change more influence upon the dynamics. The third, the time constants of hydraulics are not negligible smal compared with mass-transfer time constants.

$<$ Chemical Engineering Data $>$

Vapor-Liquid Equilibrium Data of Methanol-Ethanol-Water-Calcium Chloride System, S. Ohe, K. Yokoyama and S. Nakamura (Ishikawajima-Harima Heavy Industries Co., Ltd.

Kagaku Kōgaku, 35, 104 107 (1971)

Salt effect in vapor-liquid equilibria was studied on methanol-ethanol-water system with calcium chloride (16.7 wt.\% and saturation at room temperature) at atmospheric pressure. Relative volatility of methanol to ethanol decreases, but that of ethanol to water increases by calcium chloride.
The Motion of Single Gas Bubbles Rising in Vari. ous Liquids, H. Tsuge and S. Hibino (Keio Gijuku Univ

Kagaku Kögaku, 35, 65 71 (1971

The terminal velocity and the variation of the path and the shape of ellipsoidal single air bubbles ris

in eleven liquids of low-viscosity were measured.

The path of a single bubble was zig-zag in ma cases, but in purified water and in some organ liquids it was spiral when the diameter of the bubble was small. The period and the amplitude of the zi are of the modes of the motion.

The period of the variation of the shape which was Teasured as the ratio of the major and the minor was of a bubble was approximately half as that of the ariation of the path.

The period of the variation of the angle between the major axis of the bubble and the horizontal axis was also measured and just the same as that of the path, but the phase difference existed between these wo variations.

Taking into considerations above experimental re viscosity liquids were proposed.

Relative Movement of Particles in the Swarm of Them, T. Miyauchi and T. Yamada (Univ. of Tokyo) Kagaku Kōgaku, 35, 71 77 (1971)

To know the fundamental aspects of particle-fluid contacting operations, the relative movement of a tracer particle in the swarm of bed particles has been investigated experimentally by using a liquid fluidized bed, where the tracer particle has a size different from that of bed particles. The quantity $\phi$ as defined by Eq. (10) to give the slip velocity of the tracer particle is found a sole function of void frac tion in the bed when the particle Reynolds number veries with both of the Reynolds number and the void fraction. The quantity is also shown to give a good description for the relative rate of settling of particles with mixed particle sizes.

Continuous Phase Mass Transfer from Single Drops in Liquid-Liquid System, T. Shirotsuka and A. Hirata (Waseda Univ.

Kagaku Kögaku, 35, 78〜84 (1971

The author previously reported an analytical theory for mass transfer through a laminar boundary layer

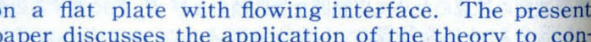
tinuous phase mass transfer from single drops. In addition, the approximate equation to evaluate the interfacial velocity of the drops is derived for a wide range of physical properties and Reynolds number. The existing data for continuous phase mass trans fer from single drops is rearranged and compared with the theoretical results. It is found that the exist ing data agree well with the theoretical results and is well correlated as a reasonable additional function of the interfacial velocity with the same degree of accuracy as that of the data for single solid spheres. for future studies of interfacial mass transfer. 